\title{
143 淁野三千三，鼠田幸旅，和田繁子：
}

結核菌に含まるる枝鍞脂肪酸類の合成研究（第六報）

フチオン酸に關する䃑究 (IV) エチル・ノニル・ドデチル錯酸, トリ・イン

アミル錯酸及びメチルデインブチル錯酸の合成

著者等は前回 ${ }^{1) 2)}$ に於て(1) の如き経過で Di-n-propyl-isoamyl-essigsäure, Methyl-n-undecyl-ndodecyl-essigsäure 及び Äthyl-n-decyl-n-dodecyl-essigsäure ま合成しトリアルキル錯酸の一般合成法 に成功したが今回も本合成法を用ひて Äthyl-n-dodecyl-cyanessigsäure と, Caprinsäure とょり出発し $\tau$ Äthyl-n-no 1yl-n-donecyl-essigsäure を合成することか出來た。本物質は $\mathrm{Kp}_{0.005} 225$ 235 (浴温) の液体であつて結核結笁形成作用の有無は目下試驗中である。

又著者等は虍に Di-isoamylmalonsäure-monoäthylester に就て コルベ反應を行つて Tetra-isoamylbernsteinsäurediäthylester を得だ）が今回は(2)の如くDi-isoamyl-malonsäuremonoäthylester とインカ プロン酸との混合物を電解して Tri-isoamyl-essigsäureäthylester 合成する事が出來た。本エステルは

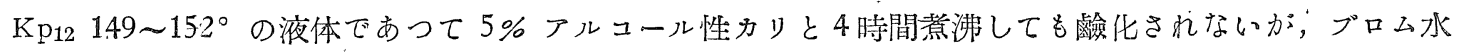
素酸の飽和溶液と共に封管中で $130^{\circ}$ に加熱すれば始めて簽化されて Tri-isoamyl-essigsäure（Fp 89〜 $91^{\circ}$ の板狀結晶）となる。本エステルがアルコール性カリで鹼化されない点に著者等は重要なる意義を 認める. 即ち Anderson3) 等は結核菌より得たフチオン酸を其のメチルェステルとしてて覆精溜し單一 なる溜分をとり之を簡單にアルコール性カリで噞化して何等困難なくフチオン酸を單離してるるのであ る。Robinson4) はフチオン酸に対して一種のトリアルキル錯酸なる構造を推定してるるが其のエステル の易嶮化性なる事は前述の如くトリアルキル錯酸としては受け入れ難くRobinson の推定は考慮を要す るものと思はれる。著者等は目下高級トリアルキル錯酸に就いて此の点を一層吟味してるる。次に Tetra-isoamyl-bernsteinsäurediäthylester も亦アルコール性カリで檢化されないでブロム水素酸（加压 下）により始めて畧化されることが認められた。

最後に著者等は（3）の如くａの位置にメチル基を有するトリアルキル錯酸の一般合成法に関する基礎 実驗を行つた。即ち Freylon5) の方法で Di-isobutyl-malonsäurediäthylester をナトリウムとアルユー ルとで還元して $\alpha, \alpha^{\prime}$-Di-isobutyl- $\beta$-oxy-propionsäure を作り, 之を還元して Methyl-di-isobutylessigsäure を合成した。本品はFp 40.5 -41.5の薄片狀結晶である。

本研究に当り費用の一部を交部省科学研究費及び日本学術振興会援助金を以て支弁した。弦に深く謝 意を表す。又分析を担当せられたる福田久子，石野郁子の両孃に感謝の意を表する次第である。
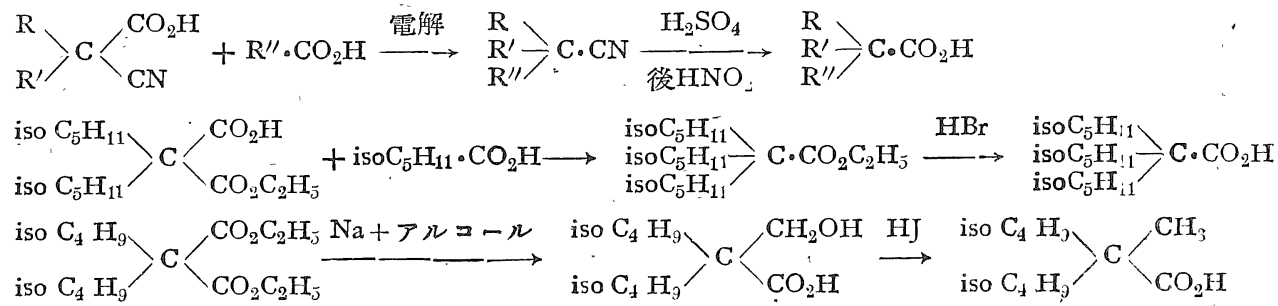

\section{實 驗之部}

1) 本誌 63,538 [昭 18] $\quad$ 2) 本誌 64, [昭 19]

3) J.biol. chem 85, 83, 84 [1929-30]; 97, 647 [1932]; 112, 763 [1935-36]

4) J.Chem. Soc. 1940, 505-509.

5) Freylon: A. ch. [8] 20,79 [1910] 
Äthyl-n-nonyldodecyl-essigsäure: Äthyl-n-dodecyl-cyan-essigsäure $3 \mathrm{~g}$ 及 び Caprinsäure $5.2 \mathrm{~g}$ に蒸溜水 $20 \mathrm{cc}$ ，アルュール $20 \mathrm{cc}$ 及び炭酸カリ $07 \mathrm{~g}$ を加へたものを電解液（酸性）とし，陽極として 螺旋狀白金線（表面積約 $1 \overline{\mathrm{cm}^{2}}$ ) を用ひ，㓌極として銅網を用ひた。約 1 アンペアの電流を通し（電圧 は14 28 ヴオルト) 電解液の温度を 40 〜 $50^{\circ}$ に保ちつつ 4 時間電解した。應成績体はエーテルに振 取し5\% 苛性ソーダに処理して酸性（原）物質を除き，エーテルを溜去すれば中性物質 $6.6 \mathrm{~g}$ を得。问 樣の实驗を 10 回行ひ全部で中性物質 $62.5 \mathrm{~g}$ を得た。之を $3 \%$ アルコール性ナトロン $192 \mathrm{cc}$ と共に 1 時間水浴上に著沸して中性物質約 $55 \mathrm{~g}$ と酸性物質とを得た。中性物質を分溜して次の 5 溜分に分け た。 $\mathrm{Kp}_{17} 99 \sim 131^{\circ} 6.3 \mathrm{~g}$ (I) $\quad \mathrm{Kp}_{2.5} 95 \sim 162^{\circ} 25.2 \mathrm{~g}$ (II), $\mathrm{K}_{\mathrm{P}_{2}} 175 \sim 200^{\circ} 3.4 \mathrm{~g}$ (III) $\mathrm{Kp}_{0.02} 173 \sim$ $210^{\circ} 5.3 \mathrm{~g}$ (IV), $\mathrm{Kp}_{0.03} 210 \sim 232^{\circ} 6.5 \mathrm{~g}$ (V)

(IV) に水醋 $32 \mathrm{cc}$ 及び $60 \%$ 硫酸 $106 \mathrm{cc}$ 故加へ直火で 6 時間募沸する。次でエーテルに振取し，エ 一テル溶液は $5 \%$ 苛性カリ及び水にて処理し酸性物質 $0.4 \mathrm{~g}$ と中性物質 $5.1 \mathrm{~g}$ とを得た。中性物質は そに水醋 $40.3 \mathrm{cc}$ 及び硫酸 $40.3 \mathrm{~g}$ を加へ水浴上に加温しつつ亞硝酸以ーダ $28 \mathrm{~g}$ を水 $56 \mathrm{cc}$ に溶解せる

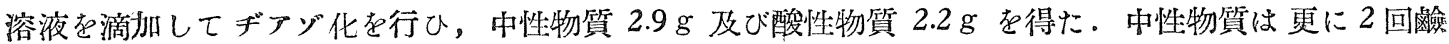

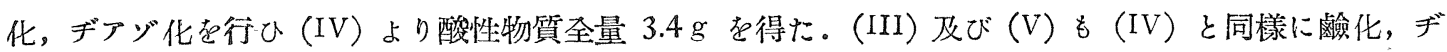
アゾ化を行ひ，酸性物質を夫々 $2 \mathrm{~g}$ 及び $3 \mathrm{~g}$ 得た。ここに得られた酸性物質合計 $8.4 \mathrm{~g}$ をエテルに 溶解し，5\% 苛性カリ及び水に処理して少量の中性物質を除き，酸性物質 $6.4 \mathrm{~g}$ を得，酸性物質は蒸溜 $し \tau \mathrm{Kp}_{1} 130 \sim 165^{\circ}$ (浴温) $07 \mathrm{~g}, \mathrm{~K}_{\mathrm{F}_{1}} 165 \sim 190^{\circ}$ (浴温) $07 \mathrm{~g}$ 及び $\mathrm{Kp}_{0.01-0.02} 170 \sim 255^{\circ}$ (浴温) $34 \mathrm{~g}$ に分ける。 $\mathrm{Kp}_{0.01-0.02} 170 \sim 255^{\circ}$ (浴温) $3.4 \mathrm{~g}$ を再三精溜して $\mathrm{KF}_{0.005} 225 \sim 235^{\circ}$ (浴温)の液体 $1.6 \mathrm{~g}$ ， を得た。

試料 $3.470 \mathrm{mg}: \mathrm{CO}_{2} 9.920 \mathrm{mg}, \mathrm{H}_{2} \mathrm{O} 4.030 \mathrm{mg}$, 一一試料 $4.050 \mathrm{mg}: \mathrm{n} / 100 \mathrm{NaOH} 1.15 \mathrm{cc}$ $\mathrm{C}_{25} \mathrm{H}_{50} \mathrm{O}_{2}$ 計算値 $\mathrm{C} 78.45, \mathrm{H} 13.18, \mathrm{CO}_{2} \mathrm{H} 11.77$ 突驗值 $\mathrm{C} 77.96, \mathrm{H} 12.99, \mathrm{CO}_{2} \mathrm{H} 12.78$

Tri-isoamyl-essigsäureäthylester : Di-isoamyl-malonsäuremonoäthylestes $8.2 \mathrm{~g}(3 / 100 \mathrm{Mol})$, イゾ カプロン酸 $10.4 \mathrm{~g}(9 / 100 \mathrm{Mol})$ 及び炭酸カリ $4.15 \mathrm{~g}(3 / 100 \mathrm{Mol})$ をアルコール $20 \mathrm{cc}$, 水 $40 \mathrm{cc}$ の混 液に溶解して電解液とし。一陽極として蠌旋狀白金線 (表面積約 $\overline{1 \mathrm{~cm}^{2}}$ ) を用ひ，銅網を陰極として 1 ア ンペアの電流を通し（電圧は 7 11 ヴオルト），電解液の温度を $35 \sim 41^{\circ} に$ に保ちつつ 8 時間電解した。 反應成績体はエーテルに振取し，5％苛性カカリに処理して酸性物質 $(1 \mathrm{~g})$ 艮除き中性物質 $10.5 \mathrm{~g}$ を得。 同樣の実驗を5 回行ひ中性物質 $45 \mathrm{~g}$ 㕜得た。之を $10 \%$ アルュール性カリ $672 \mathrm{cc}$ と共に水浴上に 5.5 . 時間羷化して酸性物質 $17.9 \mathrm{~g}$ 及び中性物質 $20.8 \mathrm{~g}$ を得。ここに得られた中性物質は再び $10 \%$ アルコ 一ル性カリ $336 \mathrm{cc}$ で 5.5 時間意沸したが殆ど畧化されることなく中性物質 $20.2 \mathrm{~g}$ を回收した。之を蒸 溜し $\mathrm{Kp}_{13} 115 \sim 140^{\circ} 14 \mathrm{~g}, \mathrm{Kp}_{12} 140 \sim 155^{\circ} 10.4 \mathrm{~g}, \mathrm{Kp}_{12.5} 155 \sim 163^{\circ} 2.3 \mathrm{~g}$ 及び $\mathrm{Kp}_{12.5} 165 \sim 203^{\circ} 1.8 \mathrm{~g}$

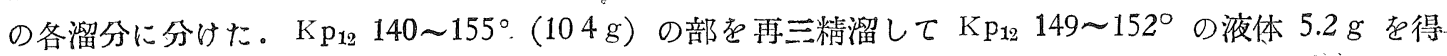

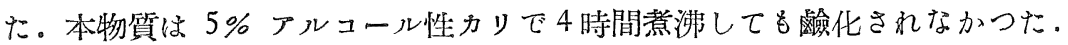

試料 $3.385 \mathrm{mg}: \mathrm{CO}_{2} 9.480 \mathrm{mg}, \mathrm{H}_{\mathbf{2}} \mathrm{O} 3.905 \mathrm{mg}$

$\mathrm{C}_{19} \mathrm{H}_{38} \mathrm{O}_{2}$ 計算值 $\mathrm{C} 76.43, \mathrm{H} 12.84$ 実驗值 C $76.38, \mathrm{H} 12.91$

Tri-isoamyl-essigsäure：Tri-isoamyl-essigsäureäthylester $2 \mathrm{~g}$ にブロム水素酸の $0^{\circ} に$ 於ける飽和 溶液 $5 \mathrm{cc}$ を加へ封管中で $130^{\circ} に 13$ 時間加熱する。反應成績体を水にて稀釈後エーテルに振取し，エ 一テル溶液を $5 \%$ 苛性カリ及び水にて交互に処理すれば酸性物質は水層に移行して來る。立に得られた 酸性物質を減压蒸溜すれば $172 \sim 173^{\circ}(12 \mathrm{~mm})$ に溜出し直に固化する。得量 $0.9 \mathrm{~g}$ 之文水醋より再結 晶すれば Fp 89〜910 の無色板狀結晶となる。

試料 $3.455 \mathrm{mg}: \mathrm{CO}_{2} 9.600 \mathrm{mg}, \mathrm{H}_{2} \mathrm{O} 3.960 \mathrm{mg}$

$\mathrm{C}_{17} \mathrm{H}_{34} \mathrm{O}_{2}$ 計算值 $\mathrm{C} 75.48, \mathrm{H} 12.68$ 実驗值 $\mathrm{C} 75.78, \mathrm{H} 1282$ 
少 Tri-isoamyl-essigsäureäthylester は之をヨード水素酸（比重 1.4），或は $60 \%$ 硫酸及び氷醋と 5.5 時間意沸したが鹼化されなかつた。

Tetra-isoamyl-bernsteinsäureanhydrid: Tetra-isoamyl-bernsteinsäurediäthylester1) $2 \mathrm{~g}$ にブロム 水素酸の $0^{\circ}$ に於ける能和溶液 $5 \mathrm{cc}$ を加へ封管中にて $120 \sim 130^{\circ} に 16$ 時間熱する。反應成績体をエー テルに振取しエーテル溶液は $5 \%$ 岢性ソーダ及び水にて交互に処理したか酒夋性物質を捕足することが出 來なかつた。其処でエーテルを溜去して褐色粘稠な液体 $1.9 \mathrm{~g}$ を得た。本物質 $1.4 \mathrm{~g}$ を\% $5 \%$ アルー ル性ナトロン $16 \mathrm{cc}$ と共に水浴上に 5 時閒霯化したところ少量の中性物質と共に酸性の結晶を得た。酸 性物質は減压下 $160 \sim 180^{\circ}$ に加熱し。蒸溜すれば $\mathrm{Kp}_{0.05} 145 \sim 150^{\circ}$ で全部溜出する。之を再溜し浴 温 $155 \sim 175^{\circ}(0.035 \mathrm{~mm})$ に溜出する非常に粘稠な無色液体を得。

試料 $3.890 \mathrm{mg}: \mathrm{CO}_{2} 10.760 \mathrm{mg}, \mathrm{H}_{2} \mathrm{O} 3.955 \mathrm{mg}$

$\mathrm{C}_{24} \mathrm{H}_{44} \mathrm{O}_{3}$ 計算值 $\mathrm{C} 75.72, \mathrm{H} 11.66$ 実驗值 C $75.44, \mathrm{H} .11 .37$

Methyl-di-isobutyl-essigsåure： $\alpha, \alpha^{\prime}$-Di-isobutyl- $\beta$-oxy-propionsäure $3.3 \mathrm{~g} に \exists$ に水素酸（比 重 1.7） $25 \mathrm{cc}$ 及び赤燐 $0.9 \mathrm{~g}$ を加へ 6 時間軽く煮沜する。冷後水を加へ油狀物質をエーテルに振取し， 之より粘稠なる液体を得る。之に亞鉛末 $11 \mathrm{~g}$ 及び氷醋 $33 \mathrm{cc}$ を加へ 1 時間煮沸後亞鉛末を濾去し，水 醋を溜去し，水を加へ，析出した油狀物質をエーテルに振取する。エーテル溶液は $5 \%$ 苛性ンーダで処 理し水層を稀硫酸々性にすれば油狀物質が析出する。之をエーテルに振取し，エーテルを溜去して得た

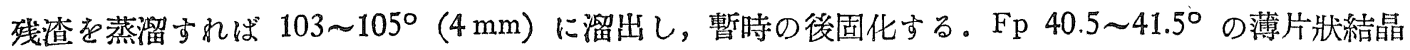
試料 $4.390 \mathrm{mg}: \mathrm{CO}_{2} 11.500 \mathrm{mg}, \mathrm{H}_{2} \mathrm{O} 4.645 \mathrm{mg}$

$\mathrm{C}_{11} \mathrm{H}_{22} \mathrm{O}_{2}$ 計算值 $\mathrm{C} 70.90, \mathrm{H} 11.98$ 実驗值 C $71.24, \mathrm{H} 11.84$

東京帝國大学傳染病研究所第六研究部（昭和 20 年 1 月 9 日受理） 